\title{
THE NSW MIDWIVES' DATA COLLECTION 1990
}

\section{Contents}

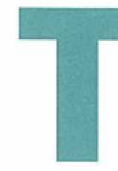
he NSW Midwives' Data Collection (MDC), previously known as the Maternal and Perinatal Data Collection, is a Statewide surveillance program which monitors patterns of pregnancy care services and pregnancy outcomes. For every birth in NSW the attending midwife completes a form (or its electronic equivalent) giving demographic, medical and obstetric information on the mother, and information on the labour, delivery and condition of the infant. The forms are sent to the Epidemiology and Health Services Evaluation Branch, where they are checked and compiled into a database.

The MDC has existed for several years, and reports on births in 1986 and 1987 have been published ${ }^{1,2}$. MDC staff have concentrated on improving the timeliness of reporting, and this article presents preliminary results for births in the first six months of 1990 . The $1990 \mathrm{MDC}$ was streamlined considerably compared with that of previous years and a new, simplified data collection form was issued. While this omits some of the detail obtained in the past, it includes for the first time items on epidural anaesthesia and episiotomy.

In the past the MDC relied on the goodwill and enthusiasm of midwives and hospital administrators, whose cooperation in complying with notification procedures has been excellent. Under a Regulation of the Public Health Act passed in November 1991, births must now be notified, and all the particulars required on the Midwives' Data Collection form must be supplied. While this does not alter the long-established practice of midwives and hospitals, it provides a statutory basis for the surveillance of pregnancy outcomes.

\section{SCOPE AND DEFINITIONS}

The Collection records information on births of liveborn or stillborn infants of at least 20 weeks' gestation or having a birthweight of at least 400 grams. Information is also available on confinements. A confinement is the delivery of one or more liveborn or stillborn infants. The delivery of twins counts as two births but one confinement.

\section{PARITY AND PLURALITY}

For the period January 1 to June 30,1990 , the Collection recorded a total of 42,969 births resulting from 42,631 confinements. Of the births, 97.7 per cent were singletons and 1.7 per cent twins. Thirty-nine per cent of the births were to primiparae (women giving birth for the first time), while 61 per cent were to multiparae (women giving birth for the second or subsequent time).

\section{OBSTETRIC INTERVENTIONS}

The proportion of births following an induced labour was lower in January-June 1990 (17.9 per cent) than 1987 (20.1 per cent). However, as Table 1 shows, the reported incidence of augmentation increased (23.4 per cent in 1990, compared with 17.4 per cent in 1987). These changes may be

\section{Articles}

13 The NSW Midwives'

Data Collection 1990

15 Notifications study reveals discrepancies

18 Infant mortality and SIDS in NSW 1969-1987

19 News and Comment

\section{Index}

20 Published articles 1990-1991

\section{Infectious diseases}

\section{Notifications}

\section{Correspondence}

Please address all correspondence and potential contributions to:

The Editor,

NSW Public Health Bulletin,

Public Health Division,

NSW Health Department

Locked Bag No 961,

North Sydney NSW 2059

Telephone: (02) 3919219

Facsimile: (02) 3919232 


\section{Midwives' Dafa Collection}

\section{Confinued from page 13}

explained partly by a change in the design of the datacollection items for augmentation and induction, with improved clarity in the new form.

The proportions of births by caesarean section and forceps delivery were slightly lower in January-June 1990 than 1987 (Table 2). Use of the ventouse and forceps rotation delivery were recorded for the first time as separate categories in 1990 . Of the 5,565 births by forceps, 761 (1.8 per cent of all births, January-June 1990) followed forceps rotation deliveries.

Episiotomies were reported as having been done for a total of 6,699 births (15.6 per cent). This figure is unexpectedly low, and probably reflects under-reporting. Episiotomies were reported in 23.8 per cent of births to primiparae and in 10.3 per cent of births to multiparae.

Epidural anaesthesia was reported for 7,602 births (17.7 per cent). Anecdotal evidence again suggests under-reporting is a possibility. In Level 6 hospitals the proportion of births with epidurals was 31.8 per cent, while in private hospitals it was 24.9 per cent. The proportions of births under epidural anaesthesia varied according to the type of delivery as follows:

Normal vaginal delivery

8.5 per cent

Forceps

Forceps rotation

Ventouse

Vaginal breech

Elective caesarean section

17.4

34.9

36.2

Emergency caesarean section

7.8

\section{PERINATAL OUTCOMES}

There were 22,073 births of male infants ( 51.4 per cent) and 20,614 females (48.0 per cent). Seventeen infants were of indeterminate sex, and sex was not recorded for 265 ( 0.6 per cent).

The distribution of birthweights for infants born in January-June 1990 was almost identical to that for infants born in 1987 (Table 3).

A total of 255 stillbirths and 154 neonatal deaths was notified to the MDC. Based on this, the perinatal death rate for NSW during January-June 1990 would be 9.5/1,000 total births. However, the Midwives' Collection is known to underestimate perinatal mortality, especially neonatal mortality, because the form is usually completed very soon after delivery. Definitive perinatal mortality rates depend on linkage with perinatal death registration data.

\section{Maternal Age}

Compared with 1987, the proportions of births to women in their 20s were slightly decreased, while those to women in their 30 s were slightly increased (Table 4).

\section{HeAlth AREa/REgion OF RESIDENCE}

Nearly one-quarter of all the births were to women resident in the Western Sydney and South-Western Sydney Health Areas, about 18 per cent were to women resident in the Hunter, Central Coast and Illawarra Areas, while 26 per cent were to women living in the rural Regions (Table 5).

\section{TABLE 1}

ONSET AND AUGMENTATION OF LABOUR ALL BIRTHS NOTIFIED TO THE NSW MDC, 1987 AND JANUARY-JUNE 1990

\begin{tabular}{|l|c|c|c|}
\hline Labour & $\begin{array}{c}\text { Number of } \\
\text { births (Jan- } \\
\text { June 1990) }\end{array}$ & $\begin{array}{c}\text { Per cent } \\
\text { (Jan-June } \\
1990)\end{array}$ & $\begin{array}{c}\text { Per cent } \\
(1987) \\
\mathrm{n=82,126}\end{array}$ \\
\hline Spontaneous & 20,980 & 48.8 & 54.4 \\
Augmented & 10,030 & 23.4 & 17.4 \\
Induced & 1,140 & 2.7 & 2.3 \\
(pharmacological) & 592 & 1.4 & 2.0 \\
Induced (surgical) & 5,928 & 13.8 & 15.8 \\
Induced (combined) & 3,886 & 9.0 & 8.1 \\
Nolabour & 306 & 0.7 & 0.0 \\
Other & 107 & 0.3 & 0.0 \\
Not recorded & 42,969 & 100 & 100 \\
\hline Total & \multicolumn{2}{|c}{} \\
\hline
\end{tabular}

\section{TABLE 2}

TYPE OF DELIVERY

ALL BIRTHS NOTIFIED TO THE NSW MDC, 1987 AND JANUARY-JUNE 1990

\begin{tabular}{|l|r|c|c|}
\hline Delivery & $\begin{array}{c}\text { Number of } \\
\text { births (Jan- } \\
\text { June 1990) }\end{array}$ & $\begin{array}{c}\text { Per cent } \\
\text { (Jan-June } \\
1990)\end{array}$ & $\begin{array}{c}\text { Per cent } \\
(1987) \\
\mathbf{n = 8 2 , 1 2 6}\end{array}$ \\
\hline Normal vaginal & 29,311 & 68.2 & 67.7 \\
Forceps & 5,565 & 13.0 & 13.9 \\
Ventouse & 572 & 1.3 & $\mathrm{~N} / \mathrm{A}^{*}$ \\
Vaginal breech & 631 & 1.5 & 1.4 \\
Caesarean (elective) & 3,561 & 8.3 & 8.1 \\
Caesarean (emergency) & 3,047 & 7.1 & 7.8 \\
Other/unknown & 282 & 0.7 & 1.1 \\
\hline
\end{tabular}

*Not recorded as a separate category in 1987.

\section{TABLE 3}

BIRTHWEIGHT

ALL BIRTHS NOTIFIED TO THE NSW MDC, 1987 AND JANUARY-JUNE 1990

\begin{tabular}{|l|r|c|c|}
\hline Birthweight (grams) & $\begin{array}{c}\text { Number of } \\
\text { births (Jan- } \\
\text { June 1990) }\end{array}$ & $\begin{array}{c}\text { Per cent } \\
\text { (Jan-June } \\
\text { 1990) }\end{array}$ & $\begin{array}{c}\text { Per cent } \\
(\mathbf{1 9 8 7}) \\
\mathrm{n}=\mathbf{8 3 , 0 9 8 *}\end{array}$ \\
\hline$<400$ & 49 & 0.1 & 0.1 \\
$400-999$ & 202 & 0.5 & 0.5 \\
$1,000-1,499$ & 218 & 0.5 & 0.5 \\
$1,500-1,999$ & 473 & 1.1 & 1.1 \\
$2,000-2,499$ & 1,596 & 3.7 & 3.6 \\
$2,500-4,499$ & 39,528 & 92.1 & 92.5 \\
$4,500+$ & 719 & 1.7 & 1.6 \\
Not recorded & 184 & 0.4 & 0.1 \\
\hline
\end{tabular}

*Variation in the total is due to different ways of handling missing data.

\section{TABLE 4}

MATERNAL AGE

ALL BIRTHS NOTIFIED TO THE NSW MDC, 1987 AND JANUARY-JUNE 1990

\begin{tabular}{|l|r|c|c|}
\hline Age (years) & $\begin{array}{c}\text { Number of } \\
\text { births (Jan- } \\
\text { June 1990) }\end{array}$ & $\begin{array}{c}\text { Per cent } \\
\text { (Jan-June } \\
1990)\end{array}$ & $\begin{array}{c}\text { Per cent } \\
(1987) \\
\mathrm{n=82,126}\end{array}$ \\
\hline$<15$ & 18 & 0.0 & 0.0 \\
$15-19$ & 2,385 & 5.6 & 5.6 \\
$20-24$ & 8,742 & 20.3 & 22.8 \\
$25-29$ & 15,388 & 35.8 & 38.3 \\
$30-34$ & 11,026 & 25.7 & 24.2 \\
$35-39$ & 3,861 & 9.0 & 7.8 \\
$40-44$ & 554 & 1.3 & 1.2 \\
$45+$ & 27 & 0.1 & 0.0 \\
Not recorded & 968 & 2.3 & 0.0 \\
\hline
\end{tabular}


Second, there must be a clear channel of communication to the PHU. A recommended pathway was described in an earlier Public Health Bulletin ${ }^{4}$ and will be reinforced in the information packages.

Third, a mechanism must be developed to deal with conflicting diagnoses. The new Act requires notification by doctors and hospital CEOs on clinical suspicion. Subsequent laboratory evidence in some cases may be contradictory.

Fourth, there is the problem where laboratory tests are not developed or sensitive enough to make a diagnosis. Hepatitis $\mathrm{E}$ is notifiable by laboratories under the new Act, but there is no adequate diagnostic test.

\section{CONCLUSIONS}

It would seem appropriate to inform the Committee of Revision for the ICD about the coding problems. Until ICD-10 or subsequent taxonomy clarifies the coding for some infectious diseases, it would also seem appropriate to require diagnosticians in the hospital system to flag a disease which is notifiable by some simple device of the kind suggested.

It is also time that medical records in all hospital and laboratory facilities were computerised, if only in the name of accountability by audit. It would be inordinately expensive to carry out an audit if searches were hand-made.

The impediments to effective disease notification discussed here relate only to cases from the source "Hospital Clinical" shown in Figure 1. Further barriers may be encountered in cases from the other three sources. Elucidation of these barriers could be achieved by extending this study to include all souces of diagnoses.

\section{RECOMMENDATIONS}

\section{It is recommended that:}

- a report be made to representatives of the Committee of Revision for the ICD, relating to specific coding problems;

- a clear and uniform plan be established for the identification and transmission of infectious diseases to the PHU in each hospital in NSW; all patient records in Health Department facilities be computerised in a uniform manner; and

- all pathology records pertaining to notifiable diseases be maintained on computer and regularly examined by PHU staff. Such a scheme has been recently development in the Hunter Area Pathology Service.

Rosemary Aldrich, Registrar,

Department of Microbiology and Infectious Diseases, Hunter Area Health Service

Thais A Miles, Registrar,

Public Health Unit, Hunter Area Health Service

(seconded from the Evidemiology and Health Services Evaluation Branch of the NSW Health Department)

1. Burns JE, Hendley JO. Epiglottitis. In Mandell GL, Douglas RG, Bennett JE (eds). Principles and practice of infectious diseases. Churchill Livingstone, New York, 1990.

2. Personal communication, staff of the RNH and the MMH

3. Personal communication, C. Roberts and S. Jobson.

4. Roberts C, Rubin G, Levy M. Improving infectious diseases control.

4. Roberts C, Rubin G, Levy M. Improving

\section{Midwives' Data Collection}

\section{Continued from page 14}

\section{TABLE 5}

MOTHER'S HEALTH AREA/REGION OF RESIDENCE ALL BIRTHS NOTIFIED TO THE NSW MDC, JANUARY-JUNE 1990

\begin{tabular}{|l|c|c|}
\hline Area/Region & Number of births & Per cent \\
\hline Central Sydney & 2,092 & 4.9 \\
Northern Sydney & 3,859 & 9.0 \\
Southern Sydney & 3,437 & 8.0 \\
Eastern Sydney & 1,994 & 4.6 \\
Western Sydney & 4,656 & 10.8 \\
Wentworth & 2,249 & 5.2 \\
Sth-Western Sydney & 5,679 & 13.2 \\
Central Coast & 1,807 & 4.2 \\
Hunter & 3,438 & 8.0 \\
Illawarra & 2,546 & 5.9 \\
North Coast & 2,693 & 6.3 \\
New England & 1,736 & 4.0 \\
South-East & 1,416 & 3.3 \\
South-West & 1,667 & 3.9 \\
Central West & 1,326 & 3.1 \\
Orana Far West & 1,264 & 2.9 \\
Outside NSW & 1,110 & 2.6 \\
\hline
\end{tabular}

\section{TABLE 6}

MOTHER'S COUNTRY OF BIRTH ALL BIRTHS NOTIFIED TO THE NSW MDC, 1987 AND JANUARY-JUNE 1990

\begin{tabular}{|l|r|r|c|}
\hline Country of birth & $\begin{array}{c}\text { Number of } \\
\text { births (Jan- } \\
\text { June 1990) }\end{array}$ & $\begin{array}{c}\text { Per cent } \\
\text { (Jan-June } \\
\mathbf{1 9 9 0 )}\end{array}$ & $\begin{array}{c}\text { Per cent } \\
(1987) \\
\mathbf{n = 8 2 , 1 2 6}\end{array}$ \\
\hline Australia & 31,053 & 73.0 & 73.0 \\
(non-Aboriginal) & 513 & 1.2 & 1.6 \\
Australia (Aboriginal) & 1,435 & 3.4 & 3.1 \\
New Zealand/Oceania & 3,309 & 7.8 & 9.5 \\
Europe & 2,822 & 6.7 & 5.5 \\
Asia & 1,624 & 3.8 & 3.9 \\
Middle East & 488 & 1.2 & 1.2 \\
America & 347 & 0.8 & 0.9 \\
Africa & 790 & 1.9 & 1.3 \\
Not stated & \multicolumn{3}{|c}{} \\
\hline
\end{tabular}

\section{MATERNAL COUNTRY OF BIRTH}

Births to women born in Europe declined in January-June 1990 compared with 1987 , while births to women born in Asia increased. Births to Aboriginal women also appeared to fall, although there may have been under-reporting of Aboriginality (Table 6).

Public Health Unit directors receive data, when processed and checked, on all births to residents of the Health Areas or Regions which they serve. These data, which do not contain any personal identification items, enable PHUs to investigate pregnancy outcomes and associated factors on a local basis. Requests for Area/Regional and local information on pregnancy outcomes should be directed to PHUs in the first instance.

Margaret Pym, Pamela Adelson, Ru Nguyen, Michael Frommer Epidemiology and Health Services Evaluation Branch NSW Health Department

1. Kearney M et al. NSW Maternal and Perinatal Collection Half-Yearly Report January-June 1986. NSW Health Department, Sydney, 1989.

2. Kearney M et al. 1987 Maternal and Perinatal Report. NSW Health Department, Sydney, 1990. 